\title{
Literasi Terkait Covid-19 di Media Sosial
}

\section{Qorri Aina Sofyan, Yulianti}

Prodi Manajemen Komunikasi, Fakultas Ilmu Komunikasi, Universitas Islam Bandung, Indonesia.

* qorriainas@gmail.com, yulianti@unisba.ac.id

\begin{abstract}
During the current COVID-19 pandemic, several hoaxes appeared which worsen today's circumstance. In this study, the following problem was how the Instagram account @ jabarsaberhoaks against the dissemination of hoax information during the COVID-19 pandemic. The objective of the study was to observe the use of social media Instagram based on The Circular Model of Some theory by Regina Luttrell contains of share aspect, optimize, manage, and engage against the dissemination of hoax information during the COVID-19 pandemic by Jabar Saber Hoaks (JSH). The chosen method used in the study was descriptive qualitative method and the data were analyze in a qualitative way. The results showed that the use of Instagram accounts by the JSH team could be said to be quite optimal with reference to the SOME theory stated by Lutrell. The implementation of share aspect by the JSH team provides content in the form of education and verification. As well as creating connection with the followers and the people by conducting a public complaint link. And to build the followers' trust the JSH team showed a credible information. The application of optimize aspect also quite optimal where the JSH team optimized their Instagram account by using hashtags. In optimizing the relationship with the followers the JSH team also communicate and discuss about pandemic issues with their followers in the comment column. In the manage aspect, the team does media monitoring such as, unlimited hours of Instagram content posts related to the pandemic because those issues are considered sensitive and needs verification. Although in engage aspect, it has not been optimally carried out because the team focuses more on verifying information to the public.
\end{abstract}

Keywords: Media Literacy, Hoax, Social Media, The Circular Model of Some.

Abstrak. Dalam masa pandemi COVID-19 seperti sekarang ini, banyak bermunculan berita-berita palsu (hoaks) yang semakin memperparah suasana. Pada penelitian ini, permasalahan yang diangkat ialah mengenai bagaimana akun Instagram @jabarsaberhoaks melawan penyebaran informasi hoaks selama pandemi COVID-19. Penelitian ini bertujuan untuk mengkaji penggunaan media sosial Instagram berdasarkan teori The Circular Model of Some menurut Regina Luttrell yaitu aspek share, optimize, manage, dan engage dalam melawan penyebaran informasi hoaks selama pandemi COVID19 oleh Jabar Saber Hoaks (JSH). Metode yang dipilih untuk melakukan penelitian ini ialah metode deskriptif kuantitatif dan data diolah secara kualitatif. Hasil penelitian menunjukkan bahwa penggunaan akun Instagram oleh tim JSH dapat dikatakan cukup optimal dengan mengacu pada teori SOME yang dinyatakan oleh Lutrell. Penerapan aspek share oleh tim cukup optimal dimana dalam upaya partisipasinya dalam penyebaran informasi tim JSH memberikan konten berupa edukasi dan verifikasi. Tim juga membuat koneksi dengan followers dan masyarakat adalah dengan membuka link pengaduan masyarakat. Dan untuk membangun kepercayaan followers tim JSH menunjukkan informasi yang kredibel. Penerapan aspek optimize juga cukup optimal dimana tim JSH melalui akun Instagramnya mengoptimalisasi media sosial mereka menggunakan hashtag. Untuk mengoptimalkan hubungan dengan followers tim JSH juga melakukan komunikasi dan diskusi terkait isu-isu pandemi menggunakan akun pribadi dari masing-masing individu dalam tim serta terlibat percakapan bersama followers dalam kolom komentar. Dalam aspek manage, tim melakukan media monitoring tidak membatasi waktu dalam mem-posting konten di Instagram terkait pandemi karena isu tersebut sensitif dan perlu segera diverifikasi. Akan tetapi, dalam aspek engage belum terlalu optimal dilakukan karena tim lebih berfokus pada verifikasi informasi kepada masyarakat.

Kata Kunci: Media Literasi, Hoaks, Media Sosial, Model Lingkaran SOME. 


\section{A. Pendahuluan}

Corona Virus Disease 2019 (COVID-19) telah mengubah cara kita hidup, tetapi itu tidak menghentikan orang menggunakan media sosial untuk menyebarkan disinformasi. Disinformasi, juga dikenal sebagai berita palsu, dapat didefinisikan sebagai penipuan yang disengaja kepada khalayak massa oleh aktor non-media melalui komunikasi sensasional yang tampak kredibel namun manipulatif dan tidak terbukti benar. Pakar ilmiah FibreFirst Nourmatania Istiftiani SKM mengatakan bahwa pencegahan dan penanggulangan tingkat penularan COVID-19 membutuhkan partisipasi semua warga Indonesia. Dan itu berangkat dari masing-masing individu dengan menyampaikan pemberitaan atau informasi yang baik dan betul (Finneman \& Thomas, 2018). Informasi sendiri seringkali ditentukan, diproses dan disajikan oleh pemangku kepentingan yang berbeda dengan pandangan dan kepentingan yang berbeda, yang dapat memotivasi pemberian informasi yang bias dan menyesatkan. Penelitian sebelumnya telah menunjukkan bahwa, selama krisis kesehatan masyarakat, banyak pesan kesehatan yang tidak sejalan dengan praktik terbaik komunikasi krisis yang efektif atau berisi informasi yang menyesatkan (Kaiser \& Königslöw, 2017).

Pembuat berita palsu mencoba mempromosikan sudut pandang atau keyakinan politik tertentu. Lalu, pelaku penyebar hoaks akan membuat artikel yang memancing emosi dan negatif bias para pembacanya, yang menyebabkan orang bereaksi dan berbagi informasi palsu ke sekitarnya. Kebanyakan orang sulit membedakan yang asli dari berita palsu. Ini karena berita palsu dapat ditemukan disamping informasi yang akurat (May, 2019). Dursin (2020) menjelaskan bahwa menurut data Kementerian Komunikasi dan Informatika Indonesia, 60\% media sosial adalah penipuan. Selama pandemi ini, publik menyediakan informasi tentang COVID-19 serta legalitas COVID-19 itu sendiri. Kementerian Komunikasi dan Informasi menemukan 857 berita palsu terkait virus tersebut pada minggu kedua bulan Juni. Ini sangat kontras dengan enam berita palsu COVID pada Januari 2020

Jabar Saber Hoaks merupakan program resmi pemerintah Hubungan Masyarakat Provinsi Jawa Barat dalam menangani hoaks yang beredar di masyarakat selama pandemi COVID-19. Program ini didedikasi khusus untuk mengatasi informasi hoaks yang beredar di masyarakat khususnya selama pandemi.

Jabar Saber Hoaks (JSH) Hermansyah (2020) menjelaskan bahwa dari 1 Januari 2020 hingga 4 Maret 2020, terdapat 867 pengaduan dari warga. Sebanyak 326 kasus (37,6\%) mengenai COVID-19 atau virus corona. Sejak Presiden Jokowi mengumumkan pada Senin 2 Maret 2020 kasus COVID-19 pertama di Kota Depok, jumlah keluhan dalam tiga hari terakhir semakin meningkat. Dari 326 pengaduan terkait informasi COVID-19, 44,5\% atau meningkat 145. Koordinator Jabar Saber Hoaks Retha Aquila menuturkan sejak Januari 2020, JSH telah memberi edukasi kepada masyarakat mengenai virus corona, bagaimana penularan, dan langkah prefentif yang bisa diambil. Edukasi atau klarifikasi istilah ini penting untuk disampaikan kepada seluruh lini masyarakat untuk menghindari kegelisahan dan kebingungan mengenai informasi dari beragam sumber media tentang status tahapan tersebut.

Berdasarkan latar belakang yang telah diuraikan, maka perumusan masalah dalam penelitian ini sebagai berikut: "Bagaimana aspek share, optimize, manage, dan engage pada penggunaan Instagram @jabarsaberhoaks?" Adapun tujuan dalam penelitian ini diuraikan dalam pokok-pokok berikut:

1. Mengetahui aspek share pada penggunaan Instagram akun@jabarsaberhoaks dalam melawan hoaks COVID-19.

2. Mengetahui aspek optimize pada penggunaan Instagram akun @jabarsaberhoaks dalam melawan hoaks COVID-19.

3. Mengetahui aspek manage pada penggunaan Instagram akun @ jabarsaberhoaks dalam melawan hoaks COVID-19.

4. Mengetahui aspek engage pada penggunaan Instagram akun@jabarsaberhoaks dalam melawan hoaks COVID-19.

\section{B. Metodologi Penelitian}

Penelitian ini menggunakan pendekatan yang objektif, yaitu penelitian yang bernuansa 
kuantitatif. Namun, data digali secara kualitatif, dan sebagai konsekuensinya data yang dianalisis dalam penelitian ini seluruhnya berupa data kualitatif. Selanjutnya, pemaparan mengenai analisis data dilakukan secara deskriptif, dengan demikian, penelitian ini tidak menguji hipotesis (Rinawati, 2008). Subjek penelitian yang dipilih adalah tim dari Jawa Barat Sapu Bersih Hoaks yaitu Alfianto Yustinov sebagai Fact Checker dan Rendy Handka sebagai Content Strategist. Teknik pengumpulan data yang digunakan yaitu wawancara secara mendalam, observasi, dokumentasi, dan studi pustaka.

\section{Hasil Penelitian dan Pembahasan}

Peneliti menilai bahwa tim Jabar Saber Hoaks sudah sangat tepat melakukan penyajian informasi terkait antisipasi penyebaran hoaks Covid-19 melalui media sosial Instagram. Hal tersebut sesuai dengan pendapat Fajrullah dan Yulianti (2021) dalam penelitiannya dimana penyajian data terpaut dengan permasalahan pandemi COVID- 19 di media sosial Instagram ini sangat cocok sebab sifatnya yang pas sasaran serta efisien buat menyajikan data berarti kepada khalayak pada dikala ini, tidak hanya itu penyajian data ini ialah salah satu upaya yang di jalani oleh tubuh publik pemerintah serta non- pemerintah yang di kelola di media sosial dalam menolong keterbukaan data publik kepada khalayak, sehingga khalayak memperoleh data yang faktual serta aktual menimpa permasalahan pandemi COVID- 19.

Tim Jabar Saber Hoaks sudah memenuhi karakteristik penggunaan Instagram, dimana oleh Putri dan Yulianti (2020) dijelaskan bahwa karakteristik Instagram terdiri atas transparansi, dialog dan komunikasi, jejaring relasi, dan multi opini. Dari ke empat aspek tersebut akun Instagram@jabarsaberhoaks telah memenuhi aspek transparansi yaitu dengan terbukanya informasi faktual tentang pandemi terhadap masyarakat, aspek dialog dan komunikasi yaitu adanya komunikasi dan diskusi tim Jabar Saber Hoaks bersama followers terkait isu-isu penting, dan aspek multi opini. Namun tim Jabar Saber Hoaks belum optimal dalam memenuhi aspek jejaring relasi karena belum melakukan relasi bersama pihak-pihak tertentu seperti external influencer yang dapat meningkatkan penyebaran konten.

Sementara itu, terkait dengan teori SOME yang dikemukakan oleh Luttrell (2015) juga sudah cukup optimal diterapkan oleh tim Jabar Saber Hoaks melalui akun Instagram mereka. Berikut pemaparan keempat aspek dalam teori SOME yang dilakukan oleh tim Jabar Saber Hoaks melalui akun Instagram @jabarsaberhoaks.

\section{Aspek share pada Penggunaan Instagram @jabarsaberhoaks dalam Melawan Hoaks} COVID-19

Dalam partisipasinya mengklarifikasi kebenaran informasi melalui Instagram, peneliti melihat bahwa tim Jabar Saber Hoaks sudah cukup optimal dalam menggunakan fasilitas Instagram dalam proses penyebaran informasi terkait pandemi. Hal tersebut terlihat dari cepatnya kontenkonten yang dibagikan pada halaman Instagram mereka terkait isu-isu yang memiliki urgensi tinggi. Penyampaian informasi tersebut dibuat dalam bentuk desain konten yang menarik dan caption-caption yang tepat serta diakhiri dengan kesimpulan yang juga sesuai.

Terkait poin lainnya dari aspek share yaitu connect, tim Jabar Saber Hoaks melalui akun Instagram nya menjalin koneksi dengan para followers atau masyarakat umum di akun Instagram mereka @jabarsaberhoaks dengan cara membuka link pengaduan bagi masyarakat ataupun followers yang menemukan isu-isu yang berpotensi hoaks di lingkungan sekitar mereka atau di media sosial yang mereka temui. Dengan langkah ini, maka koneksi antara tim Jabar Saber Hoaks dan masyarakat serta para followers akan semakin fleksibel sehingga arus pertukaran dan penyebaran informasi akan semakin cepat sehingga penyebaran hoaks dapat diantisipasi.

Poin lainnya dari aspek share yaitu buildtrust. Tim Jabar Saber Hoaks melalui akun Instagramnya berupaya membangun kepercayaan dari followers dan masyarakat dengan cara membuat konten-konten anti hoaks berdasarkan data yang terverifikasi. Hal tersebut terlihat dari postingan di Instagram mereka yang selalu menunjukkan informasi mengenai isu-isu hoaks dengan mengambil sumber dari situs-situs berita yang kredibel seperti kompas.com dan merdeka.com. Selain itu, tim juga mendapatkan verifikasi dari narasumber terkait yang juga dapat dipertanggung jawabkan pernyataannya. 


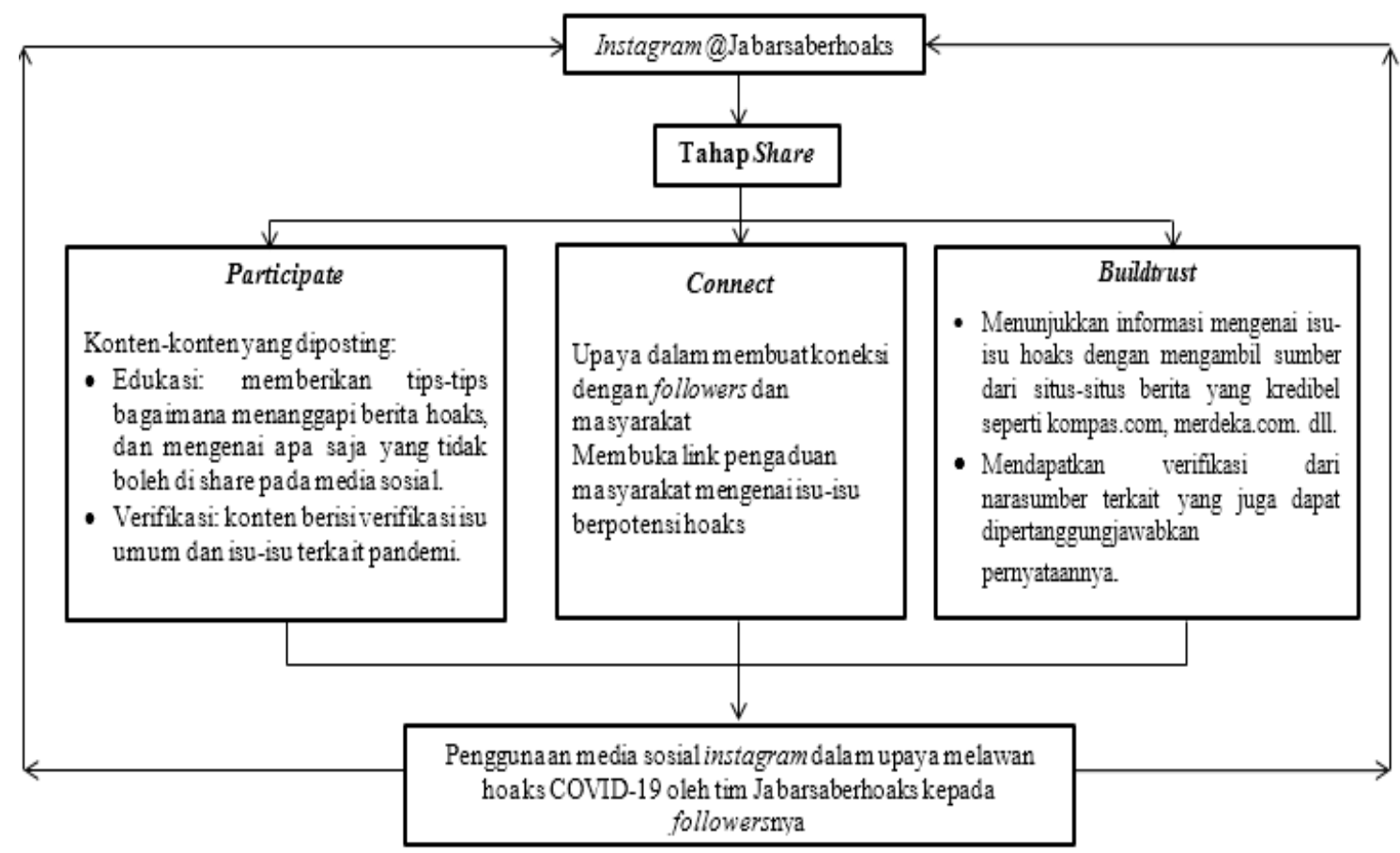

Gambar 1. Model Penggunaan Aspek Share

Sumber: Olah Data Penelitian, 2021

\section{Aspek optimize pada Penggunaan Instagram @jabarsaberhoaks dalam Melawan Hoaks COVID-19}

Langkah yang dilakukan oleh tim Jabar Saber Hoaks melalu akun Instagram untuk mengoptimalkan penggunaan akun Instagram dalam upaya anti hoaks terkait COVID-19 adalah dengan memanfaatkan hashtag dan rujukan untuk setiap postingan di Instagram @jabarsaberhoaks.

Hashtag \#Jabarsaberhoaks dan \#Jabarhantamhoaks hampir selalu dipakai oleh tim ketika memposting konten di akun Instagram mereka agar memudahkan bagi followers mereka untuk mencari informasi terkait isu yang diangkat.

Upaya mendengarkan dan mencari tahu (listen \& learn) apa yang sedang hangat dibicarakan publik nya, tim Jabar Saber Hoaks melakukan upaya tersebut secara online. Hal tersebut dilakukan dengan memantau dari lini masa (timeline) di dinding Instagram untuk melihat isu apa yang sedang ramai dibicarakan publik. Setelah mendapatkan isu yang cukup meragunkan komunitas Indonesia Hoakses bisa langsung untuk menganalisa isu tersbut. Pada masa pandemi ini pemerintah Jabar memerintahkan kepada tim untuk mengangkat semua isu terkait pandemi, karena isu tersebut sangat sensitif di masyarakat pada saat ini.

Selain itu, poin pada tahap optimize selanjutnya adalah bagaimana tim Jabar Saber Hoaks melibatkan diri dalam suatu percakapan (take part in authentic conversation). Berkenaan dengan hal tersebut, upaya yang dilakukan oleh tim Jabar Saber Hoaks adalah mereka menggunakan akun masing-masing untuk berdiskusi dengan akun lain tidak jarang juga menggunakan akun @jabarsaberhoaks untuk berdiskusi guna membangun ketertarikan followers. 


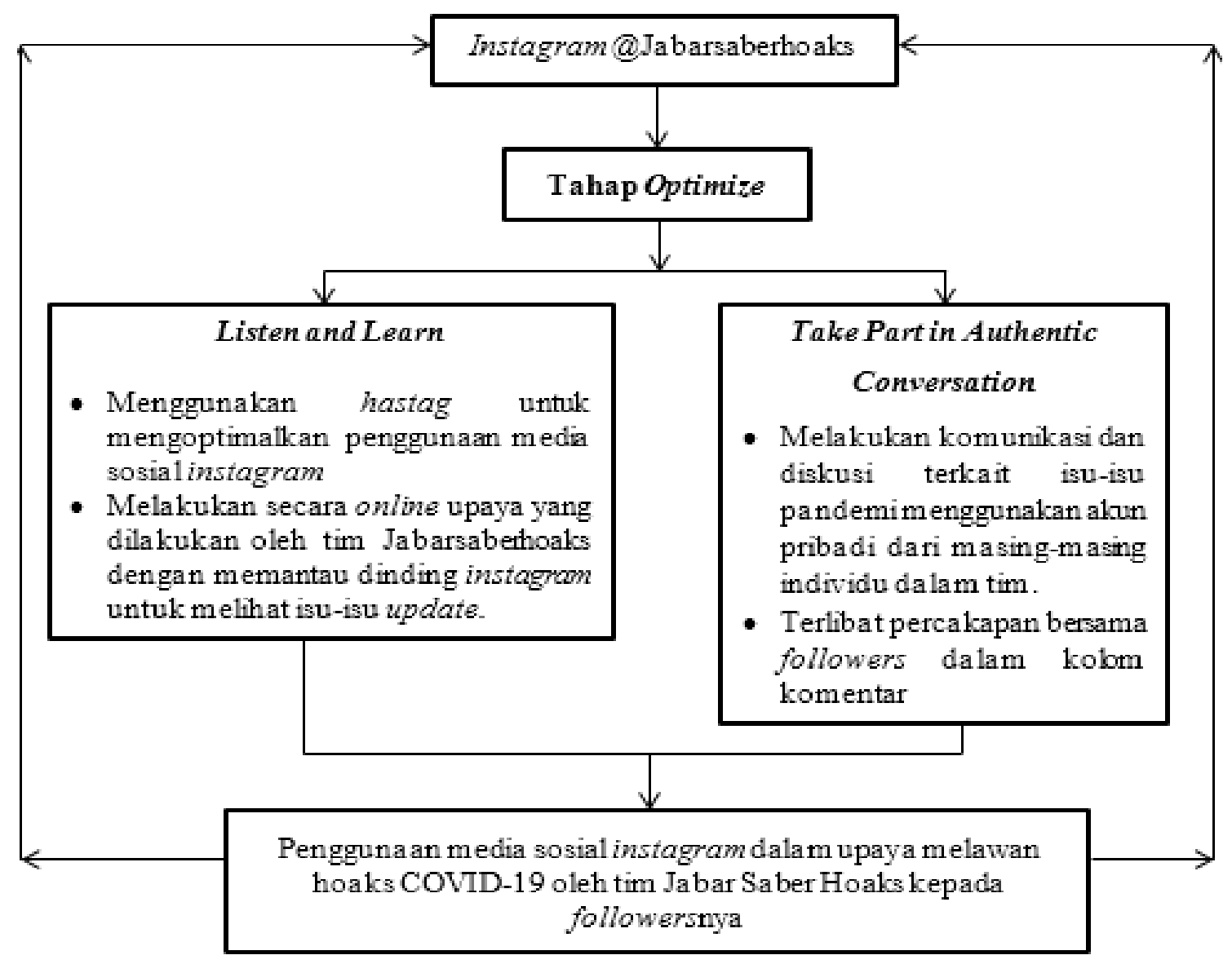

Gambar 2. Model Penggunaan Aspek Optimize

Sumber: Olah Data Penelitian, 2021

Aspek manage pada Penggunaan Instagram @jabarsaberhoaks dalam Melawan Hoaks COVID-19

Dalam mengelola media sosial Instagram @jabarsaberhoaks, tim dari Jabar Saber Hoaks sebenarnya punya prime time tersendiri dalam memposting yaitu sesuai dengan hasil wawancara yaitu sekitar pukul 10 pagi atau jam 7 sampai jam 8 malam. Akan tetapi, berkenaan dengan isu mengenai pandemi, tim Jabarasaberhoaks menyatakan bahwa mereka tidak membatasi waktu dalam memposting, karena isu mengenai pandemi sangat sensitif dan perlu untuk segera diverifikasi kepada masyarakat.

Poin kedua dalam aspek manage adalah bagaimana tim Jabar Saber Hoaks melakukan realtime interaction di Instagram. Dalam tahap ini, subjek harus mampu berinteraksi pada waktu sebenarnya. Luttrell mengatakan bahwa dengan menggunakan tools seperti Tweetdeck dan Hootsuite, perusahaan atau organisasi dapat berinterkasi dengan audiens secara realtime. Menurut pernyataan informan, tim Jabar Saber Hoaks lebih banyak melakukan interaksi secara realtime pada media sosial seperti DM atau kolom komentar Instagram, Facebook dan WhatsApp.

Selanjutnya poin ketiga dari aspek manage adalah quick response (respon cepat). Tim Jabar Saber Hoaks melalui informan menyatakan bahwa respons mereka cukup cepat dalam melayani pengaduan masyarakat baik itu melalui direct message di Instagram, atau pun pada akun-akun media sosial lainnya seperti WhatsApp dan Facebook. 
Selain itu, kemampuan tim dalam membalas pada kolom komentar Instagram dari followers juga cukup baik dan cepat. Hal tersebut karena pada kondisi saat ini jumlah komentar pada setiap postingan mereka yang tidak terlalu banyak sehingga masih mampu dikelola dengan baik oleh admin dan tim yang lainnya.

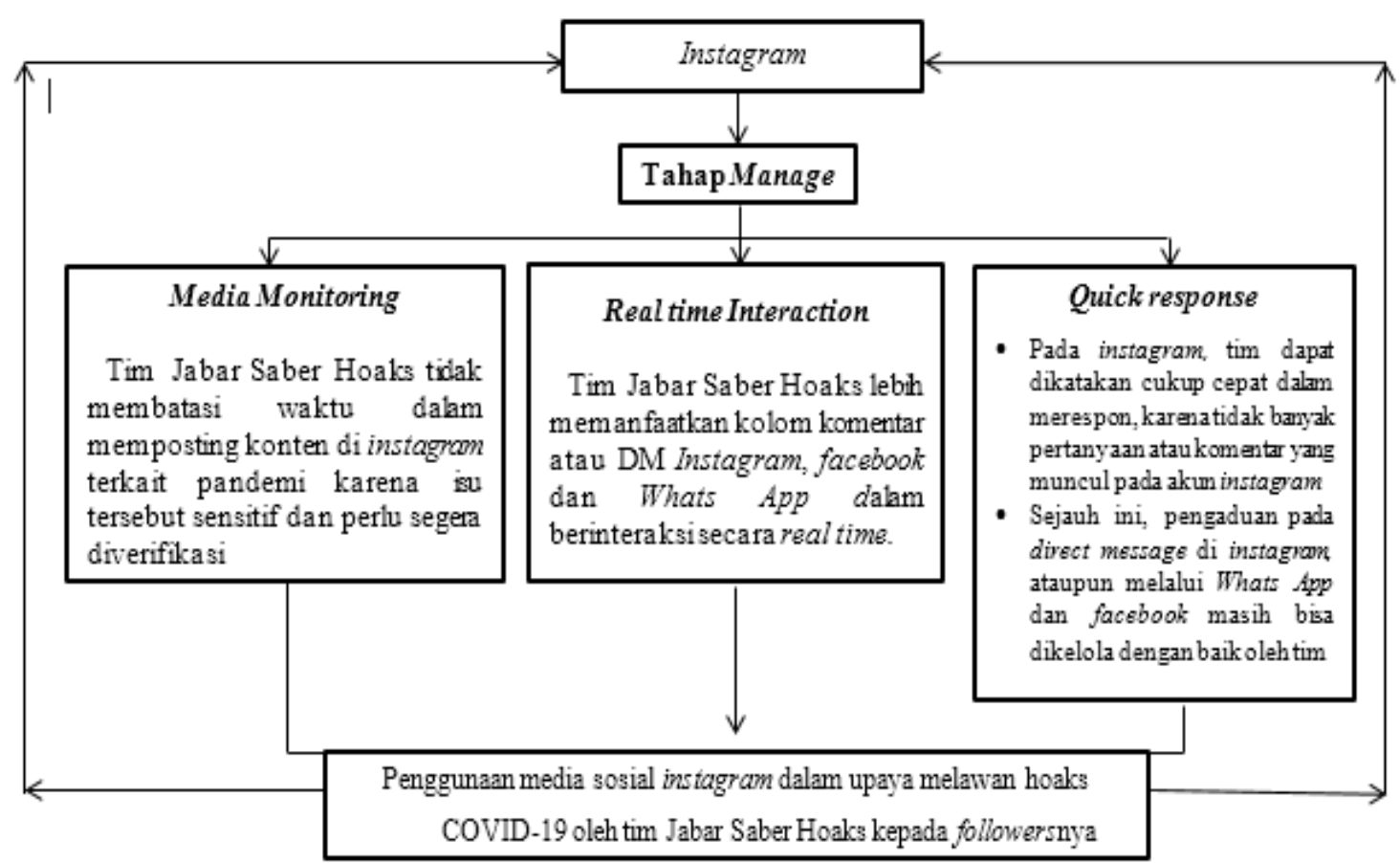

Gambar 3. Model Penggunaan Aspek Manage

Sumber: Olah Data Penelitian, 2021

\section{Aspek engage pada Penggunaan Instagram @jabarsaberhoaks dalam Melawan Hoaks COVID-19}

Dalam pengelolaan media sosial, melibatkan audience dan influencers merupakan komponen yang sangat penting dalam strategi media sosial (Mahmudah dan Rahayu, 2020). Poin mengenai keterlibatan influencer relations diketahui bahwa strategi influencer relations dibangun oleh tim Jabar Saber Hoaks masih pada internal tim saja, belum memanfaatkan external influencer. Tim menyatakan bahwa sudah ada planning memanfaatkan external influencer namun belum dilakukan saja.

Kemudian untuk poin where the audience atau mengenai dimana keterlibatan audience dalam konten-konten mereka tersebut dapat dinilai secara langsung oleh tim Jabar Saber Hoaks melalui konten-konten mereka yang diposting ulang oleh audience. Namun pada dasarnya, tim lebih berfokus pada informasi tersebut diketahui oleh masyarakat sehingga dapat mengurangi penyebaran hoaks, terutama di saat pandemi. 
Terkait dengan poin how do I reach them, diketahui bahwa tim Jabar Saber Hoaks belum terlalu fokus mengenai tindakan apa yang dilakukan untuk memaksimalkan keterlibatan followers dalam konten-konten mereka, karena mereka lebih fokus pada penyampaian klarifikasi informasi pada followers dan masyarakat. Namun pada dasarnya, mereka tetap ingin direspons dengan baik oleh followersnya melalui konten-konten mereka yang direpost oleh followers tersebut. Melalui pernyataan mas Rendy juga diketahui bahwa target tim Jabar Saber Hoaks untuk mendapatkan like dari followers untuk setiap konten nya adalah minimal 5000 likes. Namun target tersebut masih cukup jauh dari kenyataan yang ada di lapangan.

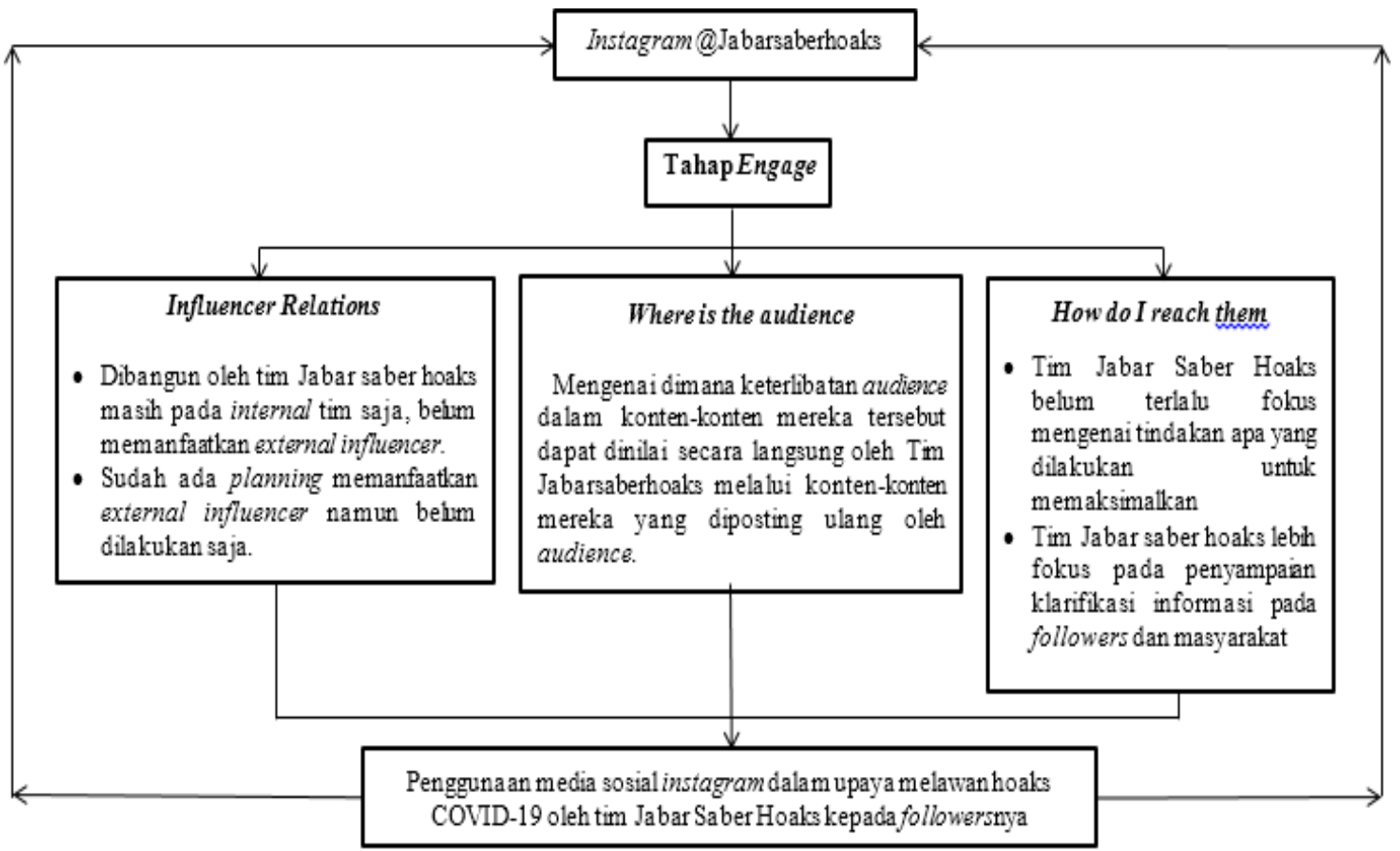

Gambar 4. Model Penggunaan Aspek Engage

Sumber: Olah Data Penelitian, 2021

\section{Kesimpulan}

Berdasarkan pembahasan dalam penelitian ini, peneliti menyimpulkan beberapa hasil penelitian sebagai berikut:

Berdasarkan aspek share dapat dilihat bahwa konten-konten yang diposting oleh tim Jabar Saber Hoaks dalam akun Instagram mereka memiliki nilai edukasi yang memberikan tipstips bagaimana menanggapi berita hoaks, dan mengenai apa saja yang tidak boleh di share pada media sosial serta berisi verifikasi yang merupakan konten berisi klarifikasi kebenaran isu umum dan isu-isu terkait pandemi. Selain itu tim juga berupaya dalam membuat koneksi dengan followers dan masyarakat dengan membuka link pengaduan masyarakat mengenai isu-isu berpotensi hoaks, serta membangun kepercayaan masyarakat dengan mengambil sumber yang kredibel.

Kemudian berdasarkan aspek optimize, tim Jabar Saber Hoaks juga mengoptimalkan dengan penggunaan hashtag dan melakukan diskusi-diskusi dengan followers baik di akun Instagram@jabarsaberhoaks maupun di Instagram pribadi mereka masing-masing.

Aspek manage juga dikelola dengan baik oleh tim Jabar Saber Hoaks melalui media monitoring secara kontinu karena mereka tidak membatasi waktu untuk melakukan pemostingan konten, selain itu mereka juga cukup cepat tanggap dalam menjawab pertanyaan dan pengaduan dari masyarakat. 
Akan tetapi, pada aspek engage dapat dipahami bahwa tim Jabar Saber Hoaks memang mengakui mereka belum membuat strategi bagaimana melibatkan followers dan masyarakat dalam akun Instagram mereka. Karena mereka lebih berfokus kepada sampainya informasi secara benar kepada masyarakat sehingga bisa mengantisipasi penyebaran hoaks.

\section{Acknowledge}

Penelitian ini dapat selesai dengan bantuan, bimbingan, dan dorongan serta kritik dan saran yang sangat berarti dari berbagai pihak. Terima kasih kang Alfianto dan kang Rendy di Jabar Saber Hoaks yang telah menjadi narasumber utama, meluangkan waktu untuk memberikan informasi demi peneliti mendapatkan data yang dibutuhkan, serta Mas Eko selaku informan pendukung. Kepada Ibu Yulianti yang mendampingi dari awal hingga penelitian ini rampung, Ibu Indri, Bu Dedeh, Pak Septiawan, Pak Aziz serta seluruh dosen dan staff Fikom. Terima kasih kepada orang-orang terkasihku mamah, papah, kakak, teman-teman serta berbagai pihak atas doa, kasih sayang, dukungan, pengorbanan dan kesabaran yang tak hentinya kalian berikan tanpa pamrih.

\section{Daftar Pustaka}

[1] Post. Retrieved December 2020 (https://www.bangkokpost.com/opinion/opinion/1946480/hoax-stories-hamper-indonesiascovid-19-fight).

[2] Fajrullah, Mochamad Rifky, and Yulianti. 2021. "Fungsi Media Sosial Dan Penyajian Informasi Terkait Pandemi Covid-19." Prosiding Manajemen Komunikasi 7.

[3] Finneman, Teri, and Ryan J. Thomas. 2018. "A Family of Falsehoods: Deception, Media Hoaxes and Fake News." Newspaper Research Journal 1-12. doi: $10.1177 / 0739532918796228$.

[4] Hermansyah. 2020. "Jabar Saber Hoaks Klarifikasi 54 Hoaks Dan Edukasi COVID-19." HUMAS JABAR Dursin, Kanis. 2020. "Hoax Stories Hamper Indonesia's Covid-19 Fight." Bangkok Kepala Biro Humas Dan Keprotokolan Sekretariat Daerah Jabar. Retrieved December 14, 2020 (http://humas.jabarprov.go.id/jabar-saber-hoaks-klarifikasi-54-hoaksdan-edukasi-covid-19/3029).

[5] Kaiser, Johannes, and Katharina Kleinen-von Königslöw. 2017. "Partisan Journalism and the Issue Framing of the Euro Crisis: Comparing Political Parallelism of German and Spanish Online News." Journalism. doi: 10.1177/1464884916683548.

[6] Luttrell, Regina. 2015. Social Media: How to Engage, Share and Connect. London: Rowman \& Littlefield Publishers.

[7] Mahmudah, Siti Muslichatul, and Muthia Rahayu. 2020. "Pengelolaan Konten Media Sosial Korporat Pada Instagram Sebuah Pusat Perbelanjaan." Jurnal Komunikasi Nusantara 2(1):1-9. doi: 10.33366/jkn.v2i1.39.

[8] May, Erin. 2019. "Fake News." Thompson Rivers University Library.

[9] Putri, Dian Miranti, and Yulianti. 2020. "Penerapan Karakteristik Konten Instagram @ Netflixid Pada Followers." Prosiding Manajemen Komunikasi 271-76.

[10] Rinawati, Rini. 2008. "Pola Komunikasi Terapeutik Perawat Dan Pasien Hemodialisis." MediaTor 9(1):13-28. 